\title{
Growth Analysis and Yield Response of Barley as Affected by Irrigation Regimes
}

\author{
E.H.E. El-Seidy, Kh. A. Amer* ${ }^{*}$ A.A. El-Gammaal and E.E. \\ El-Shawy* \\ Agronomy Dept., Fac. Agric., Tanta University, Tanta and *Barley \\ Res. Dept., Field Crops Res. Institute, Agricultural Research Center, \\ Giza, Egypt.
}

\begin{abstract}
7 HIS STUDY was conducted to evaluate twenty covered barley (Hordeum vulgare L.) genotypes for high yield potential and stable performance under two irrigation treatments (irrigated and water stressed). Total dry matter accumulation (TDM), leaf area index (LAI), crop growth rate (CGR), net assimilation rate (NAR), relative growth rate (RGR), relative water content (RWC), relative chlorophyll content (RCC), grain yield and biological yield were evaluated during two successive seasons 2009/10 and 2010/11 at Sakha Res. Station. All parameters studied had a negative significant effects as a result of water stress in both growing seasons, except for relative chlorophyll content, which increased under stress conditions compared with the normal irrigation. Results showed that L4 and L8 genotypes had the heaviest biological yield and grain yield, where they had the highest values of TDM, LAI and CGR especially under stress condition, as well as possessed good values of NAR, RGR and $\mathrm{RCC}$, revealing that these genotypes were more tolerant to water stress and more desirable genotypes for both stress and non-stress conditions.
\end{abstract}

Keywords : Hordeum vulgare L., Water stress, Irrigation regime, Growth analysis.

Abbreviations : TDM: Total dry matter accumulation, LAI: Leaf area index, CGR: Crop growth rate, NAR: Net assimilation rate, RGR: relative growth rate, RWC: relative water content, RCC: Relative chlorophyll content.

Barley (Hordeum vulgare L.) is the fourth grain crop both in area and production in the world after maize, wheat and rice. It has the potential to become one of the important cereal crops in Egypt.

Barley is the dominant cereal crop grown in North West Coast and North Sinai in Egypt. It is grown also in the new reclaimed lands. Most of these lands are suffering from water shortage and reduced soil fertility. The rainfed areas in Egypt cover about 120,000 hectares in the North West Coast and about 40.000 hectares in North-Sinai. Farming systems of these populations are livestock mainly sheep with barley as their main annual crop for fodder and bread-making (Noaman, 2008). 
Development of barley cultivars having the ability to grow well under drought and other environmental stresses is needed. An additional avenue is cultivation of early maturing barley cultivars before cotton, to support wheat production in Egypt for bread making in order to overcome the gap between wheat consumption and wheat production. Because barley production areas are located in different environments, developing stable barley cultivars is one of the main objectives for barley breeders. In this respect, Katta et al. (2009) and Amer (2010) reported the possibility of developing some barley genotypes combining high yield potential under a wide range of environmental stresses.

\section{Materials and Methods}

Twenty covered barley genotypes ( 2 lines from ICARDA, 14 breeding lines and three local varieties, i.e., Giza 121, Giza 126 and Giza 132 and Beacher Introduced from USA, locally named Giza118) were chosen for the study based on their reputed differences in yield performance under normal and stress conditions (Table 1). Experiments were conducted at the Experimental Farm of Sakha Agricultural Research Station, (ARC), Egypt, during the two successive seasons 2009/10 and 2010/11.

TABLE 1. Name, pedigree and origin of twenty barley genotypes.

\begin{tabular}{|l|l|l|}
\hline Genotypes & \multicolumn{1}{|c|}{ Cross Name \& Pedigree } & \multicolumn{1}{|c|}{ Origin } \\
\hline Line 1 & Giza 117/3/ACSAD 618//Aths/Lignee 686 & Egypt \\
\hline Line 2 & Giza 117/4/Kenya Research/Belle//As46/Aths*2/3rar/19-3// WI2294 & Egypt \\
\hline Line 3 & Ssn/Bda//Arar/3/Arabayan-01//CI07117-9/Deir Alla 106 & ICARDA \\
\hline Line 4 & $\begin{array}{l}\text { ACSAD1182/4/Arr/Esp//Alger/Ceres362-1- } \\
\text { 1/3/WI/5/ACSAD1180/3/ Mari/Aths*2//M-Att-73-337-1 }\end{array}$ & Egypt \\
\hline Line 5 & Giza 117/4/Kenya Research/Belle//As46/Aths*2/3/Arar/19-3//WI2294 & Egypt \\
\hline Line 6 & $\begin{array}{l}\text { ACSAD1182/Harmal-02/Salmas/4/Lignee527/NK1272/3/Nacha2// } \\
\text { Lignee 640/ Harma-01 }\end{array}$ & Egypt \\
\hline Line 7 & HOR 1657/4/GLORIA-BAR/COME-B//LIGNEE 640/.../5/G2000 & Egypt \\
\hline Line 8 & $\begin{array}{l}\text { Lignee 527/Chn-01/Gustoe/5/Alanda-01/4/WI2291/3/Api/ CM67// } \\
\text { L2966-69 }\end{array}$ & ICARDA \\
\hline Line 9 & $\begin{array}{l}\text { Alanda//Lignee527/Arar/5/Ager//Api/CM67/3/Ce1/WI2269//Ore/4/ } \\
\text { Hamra-1/6/ Lignee527/NK 1272/3/Nacha 2//Lignee 640/Harma-01 }\end{array}$ & Egypt \\
\hline Line 10 & Giza 119/3/ESCOBA/BRB2//ALELI & Egypt \\
\hline Line 11 & Giza 119/4/TOCTE//CEN-B/2*CALI92/3/MARCO/SEN//CARDO & Egypt \\
\hline Line 12 & Giza 125/3/ACSAD 618//Aths/Lignee 686 & Egypt \\
\hline Line 13 & CC 89/Saico & Egypt \\
\hline Line 14 & $\begin{array}{l}\text { ACSAD1182/Harmal- } \\
\text { 02/Salmas/5/ACSAD1182/4/Arr/Esp//Alger/Ceres362-1-1/3/WI }\end{array}$ & Egypt \\
\hline Line 15 & ACSAD 1182/Harmal-02/Salmas/3/Saico & Egypt \\
\hline Line 16 & $\begin{array}{l}\text { ACSAD1182/Harmal-02/Salmas/5/ACSAD1182/4/Arr/Esp//Alger/ } \\
\text { Ceres362 -1-1/3/WI }\end{array}$ & Egypt \\
\hline Beacher & Introduced to Egypt from USA and named Giza 118 & USA \\
\hline Giza 121 & Baladi16/Gem & Egypt \\
\hline Giza 126 & BaladiBahteem/SD729-por12762-Bc & Egypt \\
\hline Giza 132 & Rihane-05//As46/Aths*2" Aths/ Lignee686 \\
\hline
\end{tabular}

Egypt. J. Agron. 35, No. 1 (2013) 
Giza126 was the most drought tolerant variety. So, this variety was used as with the reference to compare the other genotypes.

Soil samples were randomly taken from the experimental area at a depth of 0 to $30 \mathrm{~cm}$ from soil surface before barley sowing. Soil properties are shown in Table 2. Water application was monitored via water meter as shown in Table 3.

TABLE 2. Soil analysis of the experimental field at Sakha Agricultural Research Station during 2009/10 and 2010/11 seasons.

\begin{tabular}{|c|c|c|c|c|c|c|c|c|c|c|}
\hline \multirow[t]{2}{*}{ Season } & \multicolumn{3}{|c|}{$\begin{array}{l}\text { Particle size } \\
\text { distribution }\end{array}$} & \multirow{2}{*}{$\begin{array}{l}\text { Texture } \\
\text { class }\end{array}$} & \multirow{2}{*}{$\begin{array}{c}\mathrm{EC} \\
\left(\mathrm{ds}^{-m^{-1}}\right)\end{array}$} & \multirow{2}{*}{\multicolumn{2}{|c|}{ OM \% }} & \multicolumn{3}{|c|}{$\begin{array}{l}\text { Available } \mathbf{N}, \mathbf{P}, \mathbf{K} \\
\quad\left(\mathrm{mg} . \mathrm{kg}^{-1} \text { soil }\right)\end{array}$} \\
\hline & Sand \% & Silt \% & Clay \% & & & & & $\mathbf{N}$ & $\mathbf{P}$ & $\mathbf{K}$ \\
\hline $2009 / 10$ & 13.74 & 24.91 & 61.35 & clayey & 2.1 & 1. & & IV & IT & MI \\
\hline $2010 / 11$ & 15.53 & 23.95 & 60.52 & clayey & 2.9 & & & 19 & 17 & rr. \\
\hline \multirow{2}{*}{ Season } & \multicolumn{4}{|c|}{ Anions $\left(\operatorname{meq.} \mathbf{L}^{-1}\right)$} & \multicolumn{4}{|c|}{ Cations (meq. $\mathbf{L}^{-1}$ ) } & \multirow{2}{*}{\multicolumn{2}{|c|}{ pH }} \\
\hline & $\mathrm{CO}_{3}^{--}$ & $\mathrm{HCO}_{3}^{-}$ & $\mathrm{Cl}^{-}$ & $\mathrm{SO}_{4}{ }^{--}$ & $\mathrm{Ca}^{++}$ & $\mathrm{Mg}^{++}$ & $\mathrm{Na}^{+}$ & $\mathbf{K}^{+}$ & & \\
\hline $2009 / 10$ & $\cdot, \cdot$ & r,o & $1 \leqslant, \wedge$ & r & 0,1 & r,l & $M, r$ & $\cdot, \varepsilon$ & \multicolumn{2}{|c|}{$v, q$} \\
\hline $2010 / 11$ & $\cdot, \cdot$ & $r, \wedge$ & $10,$. & $1, r$ & $0, r$ & $r, \cdot$ & $1 \varepsilon, \wedge$ & $\cdot, 0$ & \multicolumn{2}{|c|}{$\wedge, 2$} \\
\hline
\end{tabular}

TABLE 3. Amount of water supplied in $\mathrm{m}^{3}$. fed ${ }^{-1}$ at different critical growth stages of barley, rainfall amount and total water supplied in 2009/10 and 2010/11 seasons.

\begin{tabular}{|c|c|c|c|c|c|c|c|c|}
\hline \multirow{3}{*}{$\begin{array}{l}\text { Irrigation } \\
\text { treatments }\end{array}$} & \multirow{3}{*}{$\begin{array}{l}\text { Growth } \\
\text { seasons }\end{array}$} & \multicolumn{3}{|c|}{ Growth stages } & \multicolumn{4}{|c|}{ Irrigation } \\
\hline & & \multirow[b]{2}{*}{ Sowing } & \multirow[b]{2}{*}{ Tillering } & \multirow[b]{2}{*}{ Booting } & \multirow{2}{*}{$\begin{array}{c}\text { Total } \\
\text { irrigated } \\
\text { water }\left(\mathbf{m}^{3}\right)\end{array}$} & \multicolumn{2}{|c|}{ Rainfall } & \multirow{2}{*}{$\begin{array}{c}\text { Total } \\
\text { supplied } \\
\left(\mathbf{m}^{3} . \text { fed }^{-1}\right)\end{array}$} \\
\hline & & & & & & $(\mathbf{m m})$ & $\mathbf{m}^{3}$. fed $^{-1}$ & \\
\hline \multirow{2}{*}{ Irrigated } & $2009 / 10$ & 550 & 350 & 450 & 1350 & 28 & 117.6 & 1467.6 \\
\hline & 2010/11 & 500 & 325 & 450 & 1275 & 120 & 504 & 1779 \\
\hline \multirow{2}{*}{ Stressed } & $2009 / 10$ & 550 & 0 & 0 & 550 & 28 & 117.6 & 667.6 \\
\hline & 2010/11 & 500 & 0 & 0 & 500 & 120 & 504 & 1004 \\
\hline
\end{tabular}

In the first season, the maximum temperature was high and the relative humidity and rainfall were low compared with the second season (Table 4). 
TABLE 4. Maximum and minimum temperature, average relative humidity and rainfall during the growing seasons of barley crop at Sakha Agricultural Research Station (ARC), Egypt.

\begin{tabular}{|c|c|c|c|c|c|c|c|c|}
\hline \multirow{3}{*}{ Month } & \multicolumn{4}{|c|}{ Temperature $^{\circ}(\mathbf{C})$} & \multirow{2}{*}{\multicolumn{2}{|c|}{$\begin{array}{l}\text { Relative humidity } \\
\qquad \%)\end{array}$}} & \multirow{2}{*}{\multicolumn{2}{|c|}{ Rainfall (mm) }} \\
\hline & \multicolumn{2}{|c|}{ 2009/10 } & \multicolumn{2}{|c|}{$2010 / 11$} & & & & \\
\hline & Max. & Min. & Max. & Min. & 2009/10 & 2010/11 & $2009 / 10$ & $2010 / 11$ \\
\hline Dec. & 22.72 & 8.92 & 16.82 & 14.75 & 66.44 & 80.94 & 5.80 & 44.95 \\
\hline Jan. & 21.77 & 7.77 & 14.73 & 12.49 & 71.48 & 87.74 & 0.00 & 28.21 \\
\hline Feb. & 23.38 & 9.19 & 15.81 & 13.32 & 65.11 & 79.00 & 22.20 & 22.40 \\
\hline Mar. & 23.92 & 9.18 & 18.24 & 15.09 & 62.09 & 77.97 & 0.00 & 13.95 \\
\hline Apr. & 28.77 & 11.76 & 23.40 & 18.08 & 68.62 & 66.77 & 0.00 & 10.50 \\
\hline
\end{tabular}

Grains were hand sowed at the recommended sowing rate of barley in the irrigated land $\left(50 \mathrm{~kg} . \mathrm{fed}^{-1}\right)$. Each genotype was sown in six rows of $3.5 \mathrm{~m}$, spaced with $20 \mathrm{~cm}$ among rows. These experiments were laid out in a randomized complete block design with four replications. The first experiment was irrigated twice after sowing, 45 days after sowing at tillering stage and 75 days after sowing at booting stage (normal condition); the second experiment was received just sowing irrigation (drought stress condition). Sowing was done on November $15^{\text {th }}$ in both seasons. All recommended culture practices were applied at proper time according to Ministry of Agriculture recommendations. The preceding crop was cotton in the two seasons.

\section{Data recorded}

Half long meter guarded tillers were randomly taken from the second inner rows of each plot at 45, 65 and 85 days after sowing to determine growth characters. Each sample was separated into stems and leaves, and then leaf area (blades area) was measured by portable area meter (Model LI-3000A). Tillers organs were dried separately in an electrical air-draft oven at $70^{\circ} \mathrm{C}$ until constant weight for determination of whole dry weight.

Growth characters were estimated as follows:-

Crop growth rate (CGR)

At an instant in time $(\mathrm{t})$ is defined as the increase of tillers material per unit of time.

$$
\text { CGR }=\frac{\left(\mathbf{W}_{2}-\mathbf{W}_{1}\right)}{\left(\mathbf{t}_{2}-\mathbf{t}_{1}\right)} \quad \mathrm{g} / \mathrm{m}^{2} / \text { week. }
$$

where: $\mathrm{w}_{1}$ and $\mathrm{w}_{2}$ refer to dry weight at time $\left(\mathrm{t}_{1}\right)$ and $\left(\mathrm{t}_{2}\right)$, respectively, in week according to Radford (1967).

Relative growth rate (RGR)

At an instant in time ( $t)$, is defined as the increase of plant material per unit of material present per unit of time.

$$
\text { RGR }=\frac{\left(\log _{\mathrm{e}} \mathbf{w}_{2}-\log _{\mathrm{e}} \mathbf{w}_{1}\right)}{\left(\mathbf{t}_{2}-\mathbf{t}_{1}\right)} \quad \mathrm{g} / \mathrm{g} / \text { week } .
$$

RGR was calculated according to Radford (1967).

Egypt. J. Agron. 35, No. 1 (2013) 
Net assimilation rate (NAR)

At an instant in time ( $\mathrm{t}$ ), is defined as the increase of plant material per unit of material present per unit of assimilatory material per unit of time.

$$
\text { NAR }=\frac{\left(W_{2}-W_{1}\right)\left(\log _{e} A_{2}-\log _{e} A_{1}\right)}{\left(A_{2}-A_{1}\right)\left(t_{2}-t_{1}\right)} \quad \mathrm{g} / \mathrm{m}^{2} / \text { week }
$$

where: $\mathrm{w}_{1}, \mathrm{~A}_{1}$ and $\mathrm{w}_{2}, \mathrm{~A}_{2}$, respectively, refer to dry weight and leaf area at time $\left(t_{1}\right)$ and $\left(t_{2}\right)$ in week according to Radford (1967).

Leaf area index (LAI)

It is defined as total area of leaves of the plants compared with the area of land occupied by the plants according to Watson (1952) as described by the following formula:

$$
\text { L.A.I }=\frac{\text { Leaf area } / \text { tillers }\left(\mathrm{cm}^{2}\right)}{\text { Tillers ground area }\left(\mathrm{cm}^{2}\right)}
$$

Relative chlorophyll content (RCC)

The relative chlorophyll content in the flag leaf was determined using a chlorophyll meter (SPAD-502, Japan).

\section{Relative water content ( $R W C \%)$}

It was determined by the method of Barrs (1968). To determine the relative water content (RWC), the harvested leaf was cut into $12 \mathrm{~cm}$ sections, and immediately weighed (FW), then sliced into $2 \mathrm{~cm}$ sections and floated on distilled water for $4 \mathrm{hr}$. The turgid leaf discs were then rapidly blotted to remove surface water and weighted to obtain turgid weight (TW). The leaf discs were then oven dried for $2 \mathrm{hr}$ at $60^{\circ} \mathrm{C}$ and dry weight (DW) was recorded. RWC was calculated by the formula:

$$
\mathrm{RWC}=\frac{\mathrm{FW}-\mathrm{DW}}{\mathrm{TW}-\mathrm{DW}} \times 100
$$

where: $F W=$ fresh weight of leaf. $\mathrm{DW}=$ dry weight. $\mathrm{TW}=$ full turgor.

Grain yield $(\mathrm{kg} / \mathrm{fed})$

It was recorded from the grains of harvested plants/plot after threshing and then converted to $\mathrm{kg} / \mathrm{fed}$.

Biological yield $(\mathrm{kg} / \mathrm{fed})$

It was recorded from all harvested plants / plot and converted to $\mathrm{kg} / \mathrm{fed}$.

\section{Results and Discussion}

It is a well-established fact that plant structure is determined by growth parameters such as, total dry matter accumulation (TDM), leaf area index (LAI), crop growth rate (CGR), relative growth rate (RGR), net assimilation rate (NAR), relative water content (RWC) and relative chlorophyll content (RCC). 
These concepts not only involve the final crop yield and its components, but also probe into the physiological events that have occurred early in the growth stages causing variation in yield potential.

\section{Total dry matter accumulation (TDM)}

This trait was significantly affected by water stress (Table 5). In general, increasing irrigation increased TDM. TDM increased slowly at the early stages of growth and then increased rapidly with the advancement of plant age (Fig.1). The cause of rapid increase of TDM at the later stages was possibly due to the development of a considerable number of late tillers, plant height and leaf area. These results are in harmony with those of Alam (2003), Mollah \& Paul (2008) and Vaezi et al. (2010). Giza 132, L4, L5, L6 and L8 gave the highest values for TDM compared to Giza 126 in the three samples. Highly significant interaction between barley genotypes and irrigation treatments was found in the three samples. Giza 132, L4 and L8 gave the highest values of TDM compared to Giza 126 under both treatments in the three samples, which they had high values of LAI in the three samples, CGR and NAR in both growth intervals.

TABLE 5. Dry matter accumulation (TDM) means as affected by irrigation treatments and barley genotypes as well as its interaction at three growth stages in combined data of both growing seasons.

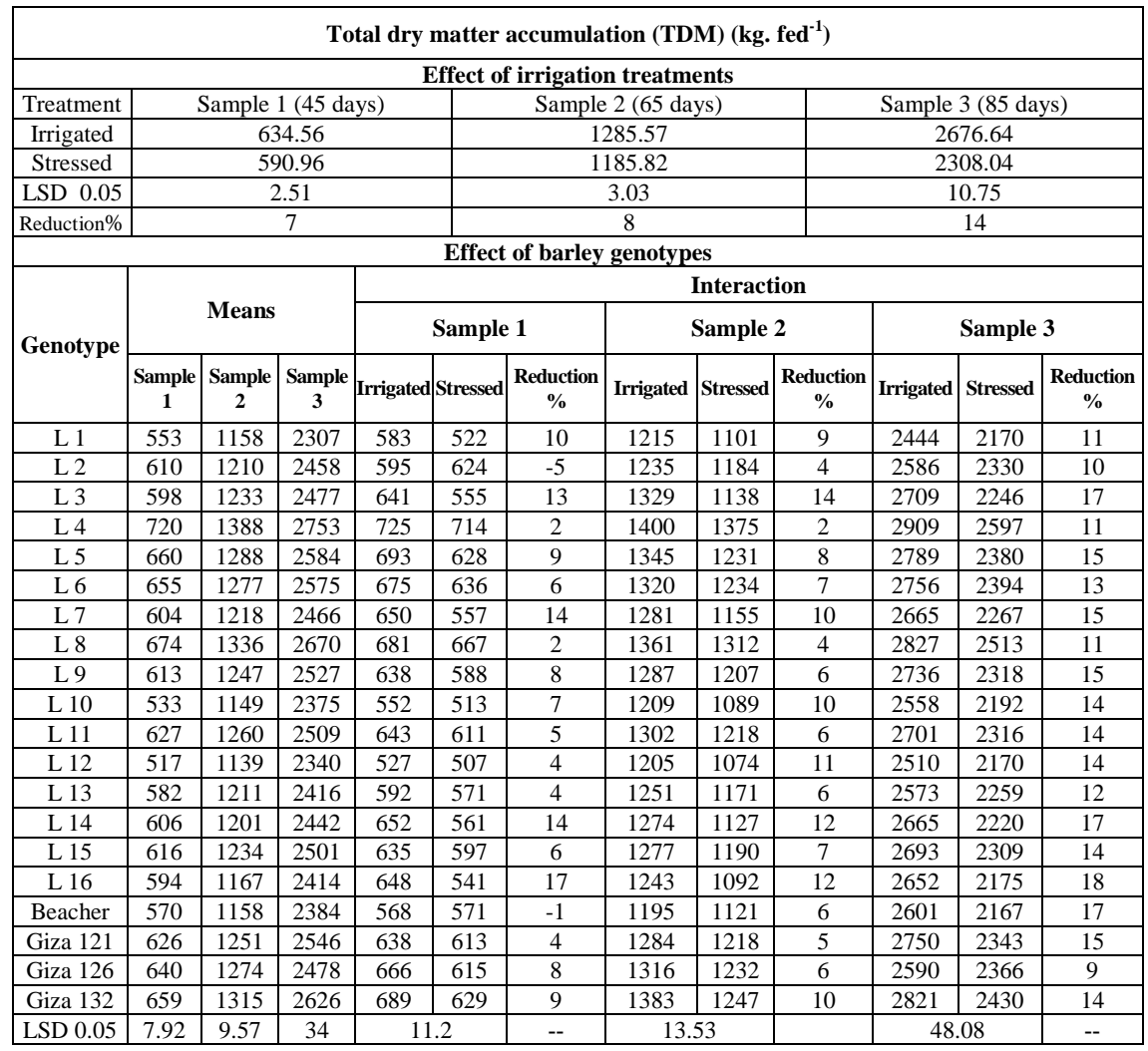

Egypt. J. Agron. 35, No. 1 (2013) 


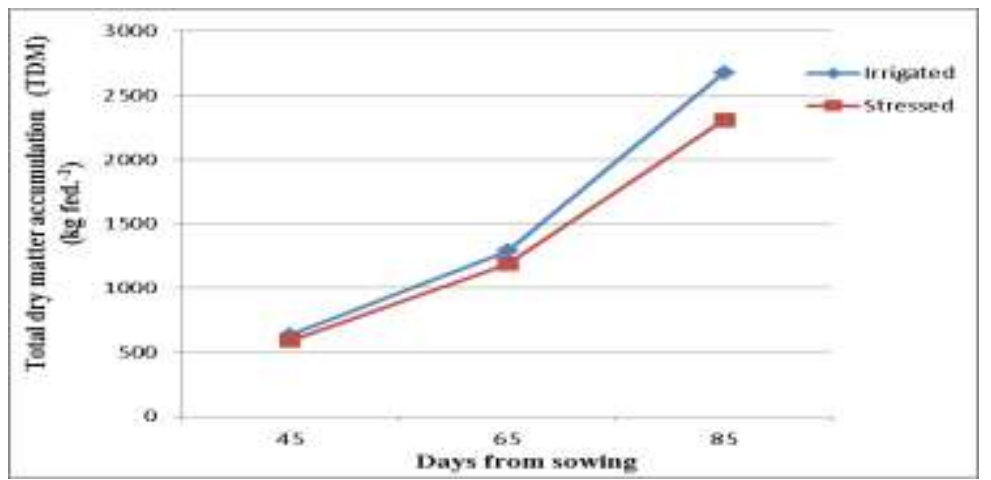

Fig. 1. Trend of total dry matter accumulation under irrigated and stressed conditions.

Leaf area index (LAI)

Leaf area index decreased with decreasing irrigation application (Table 6). The irrigated treatment had higher LAI than the stressed one. LAI (3.97, 7.87 and 5.85 at 45, 65 and 85 days, respectively) exhibited the highest value under irrigated treatment and corresponding lowest value obtained from the stressed treatment (3.85, 7.31 and 4.67 at 45,65 and 85 days, respectively). The reduction percentage was 3, 7 and $20 \%$ at 45,65 and 85 days, respectively.

LAI reached in a maximum value in the second sample and then declined with plant age in the third sample (Fig. 2). The increase of LAI occurred due to the increase of leaf expansion in the irrigated plants. Increase in soil moisture resulted in increased turgor pressure in the cells and turgor forces played a part in the process of leaf expansion ( Alam, 2003; Jazy, 2007; Mollah \& Paul, 2008 and Moayedi et al., 2011).

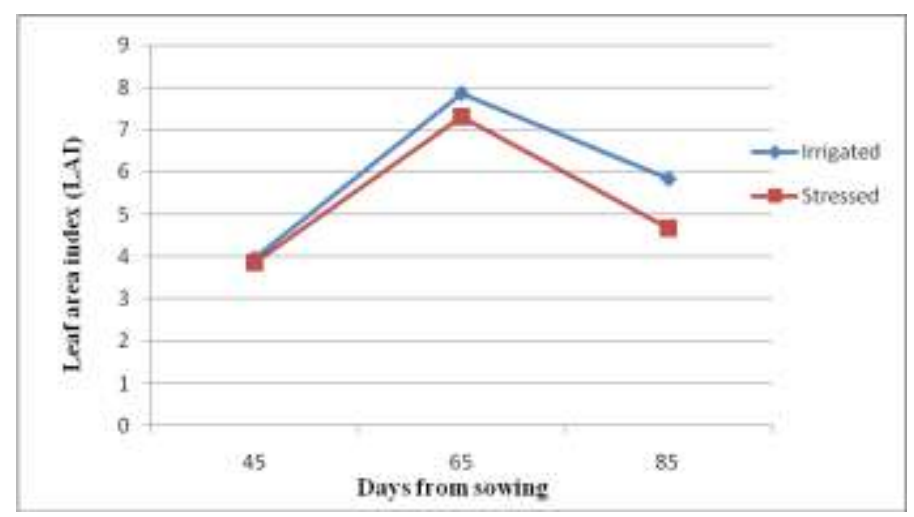

Fig. 2. Trend of leaf area index under irrigated and stressed conditions. 
TABLE 6. Leaf area index (LAI) means as affected by irrigation treatments and barley genotypes as well as its interaction at three growth stages in combined data of both growing seasons.

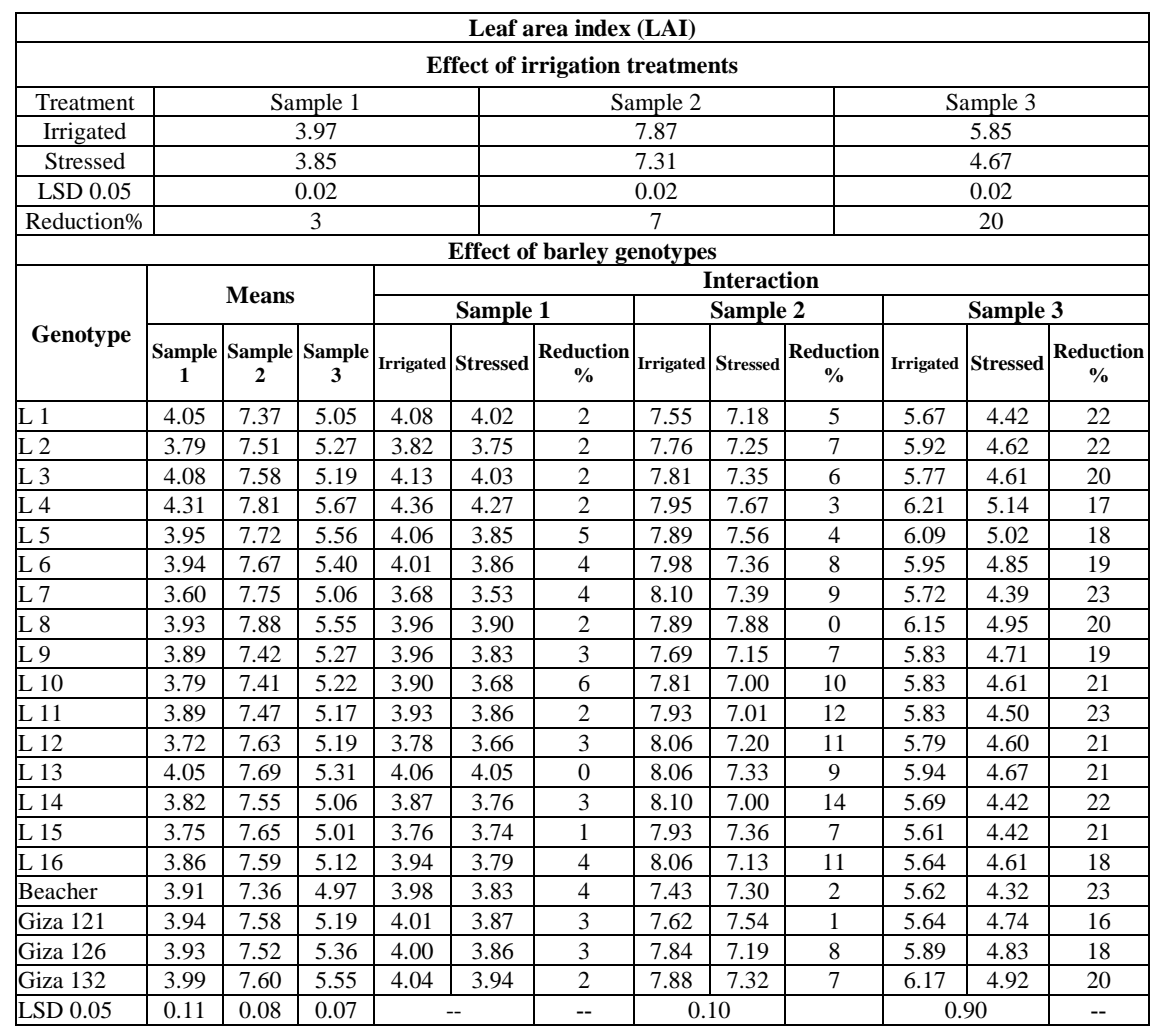

For mean values of the twenty barley genotypes, results showed highly significant differences existed between barley genotypes. Giza132, L4 and L18 had higher values especially under the stressed treatment compared to Giza 126.

\section{Crop growth rate (CGR)}

Crop growth rate means had been significantly lower in the stressed treatment than the irrigated treatment (Table 7). CGR changes resembled in both treatments, but the irrigated treatment had superiority over that of the stressed treatment during all the stages. Reduction of the CGR under water stress condition was due to reduction of the LAI and the NAR (Jazy, 2007; Mollah \& Paul, 2008 and Moayedi et al., 2011). Giza 132, L4 and L8 had the highest values in the first growth intervals, while, most genotypes exceeded Giza 126 in the second growth intervals, especially Giza 132, L4 and L8. L4 and L8 had the highest values in the two growth intervals under the stressed treatment compared to Giza 126, where they had the highest values of TDM in the three samples. 
TABLE 7. Crop growth rate (CGR) means as affected by irrigation treatments and barley genotypes as well as its interaction at two growth intervals in combined data of both growing seasons.

\begin{tabular}{|c|c|c|c|c|c|c|c|c|}
\hline \multicolumn{9}{|c|}{ Crop growth rate (CGR) $\left(\mathrm{g}^{-\mathrm{m}^{-2}} \cdot\right.$ week $\left.^{-1}\right)$} \\
\hline \multicolumn{9}{|c|}{ Effect of irrigation treatments } \\
\hline Treatment & \multicolumn{4}{|c|}{ CGR 1} & \multicolumn{4}{|c|}{ CGR 2} \\
\hline Irrigated & \multicolumn{4}{|c|}{217} & \multicolumn{4}{|c|}{463.69} \\
\hline Stressed & \multicolumn{4}{|c|}{198.28} & \multicolumn{4}{|c|}{374.07} \\
\hline LSD 0.05 & \multicolumn{4}{|c|}{1.39} & \multicolumn{4}{|c|}{3.65} \\
\hline Reduction $\%$ & \multicolumn{4}{|c|}{9} & \multicolumn{4}{|c|}{19} \\
\hline \multicolumn{9}{|c|}{ Effect of barley genotypes } \\
\hline \multirow{3}{*}{ Genotype } & \multirow{2}{*}{\multicolumn{2}{|c|}{ Means }} & \multicolumn{6}{|c|}{ Interaction } \\
\hline & & & \multicolumn{3}{|c|}{ CGR 1} & \multicolumn{3}{|c|}{ CGR 2 } \\
\hline & CGR 1 & CGR 2 & Irrigated & Stressed & Reduction \% & Irrigated & Stressed & Reduction\% \\
\hline L 1 & 202 & 383 & 211 & 193 & 9 & 410 & 356 & 13 \\
\hline L 2 & 200 & 416 & 213 & 187 & 12 & 450 & 382 & 15 \\
\hline L 3 & 212 & 415 & 229 & 194 & 15 & 460 & 369 & 20 \\
\hline L 4 & 223 & 455 & 225 & 220 & 2 & 503 & 407 & 19 \\
\hline L 5 & 209 & 432 & 217 & 201 & 7 & 481 & 383 & 20 \\
\hline L 6 & 207 & 433 & 215 & 199 & 7 & 479 & 387 & 19 \\
\hline \begin{tabular}{|l|}
$\mathrm{L} 7$ \\
\end{tabular} & 205 & 416 & 210 & 199 & 5 & 461 & 371 & 20 \\
\hline L 8 & 221 & 445 & 226 & 215 & 5 & 489 & 401 & 18 \\
\hline L 9 & 212 & 427 & 217 & 206 & 5 & 483 & 370 & 23 \\
\hline L 10 & 205 & 409 & 219 & 192 & 12 & 450 & 368 & 18 \\
\hline L 11 & 211 & 416 & 220 & 202 & 8 & 467 & 366 & 22 \\
\hline L 12 & 208 & 400 & 226 & 189 & 16 & 435 & 366 & 16 \\
\hline L 13 & 210 & 402 & 219 & 200 & 9 & 441 & 363 & 18 \\
\hline L 14 & 198 & 414 & 208 & 189 & 9 & 463 & 364 & 21 \\
\hline L 15 & 206 & 422 & 214 & 198 & 7 & 472 & 373 & 21 \\
\hline L 16 & 191 & 415 & 198 & 184 & 7 & 470 & 361 & 23 \\
\hline Beacher & 196 & 409 & 209 & 183 & 12 & 469 & 348 & 26 \\
\hline Giza 121 & 209 & 432 & 215 & 202 & 6 & 489 & 375 & 23 \\
\hline Giza 126 & 211 & 401 & 217 & 206 & 5 & 425 & 378 & 11 \\
\hline Giza 132 & 219 & 437 & 231 & 206 & 11 & 479 & 394 & 18 \\
\hline LSD 0.05 & 4.38 & 11.53 & \multicolumn{2}{|c|}{6.19} & -- & \multicolumn{2}{|c|}{16.31} & -- \\
\hline
\end{tabular}

Net assimilation rate (NAR)

The trend in NAR had a high similarity with both irrigated treatments, in which it increased at the second growth interval more than the first growth interval. This period was corresponding with the maximum LAI and dry mater accumulation period (Mollah \& Paul, 2008 and Moayedi et al., 2011). A lower NAR was found in the stressed treatment than in the irrigated treatment (Table 8). It appears that a severe decline in NAR under water stress condition was related to the high reduction in LAI and CGR, which consequently caused a severe reduction in RGR and TDM in the same phase. Under irrigated treatment, Giza 132, L3, L8 and L12 had the highest values in the first growth intervals, while, all genotypes exceeded Giza126 in the second growth intervals. Under the stressed treatment, all genotypes were lower than Giza126, except L9 and L11 were exceeded in the first growth interval, while, there insignificant different between genotypes in the second growth interval. 
TABLE 8. Net assimilation rate (NAR) means as affected by irrigation treatments and barley genotypes as well as its interaction at two growth intervals in combined data of both growing seasons.

\begin{tabular}{|c|c|c|c|c|c|c|c|c|}
\hline \multicolumn{9}{|c|}{ Net assimilation rate (NAR) ) $\left(\right.$ kg.m². week $\left.{ }^{-1}\right)$} \\
\hline \multicolumn{9}{|c|}{ Effect of irrigation treatments } \\
\hline Treatment & \multicolumn{4}{|c|}{ NAR 1} & \multicolumn{4}{|c|}{ NAR 2} \\
\hline Irrigated & \multicolumn{4}{|c|}{6.56} & \multicolumn{4}{|c|}{11.88} \\
\hline Stressed & \multicolumn{4}{|c|}{6.34} & \multicolumn{4}{|c|}{11.15} \\
\hline LSD 0.05 & \multicolumn{4}{|c|}{0.05} & \multicolumn{4}{|c|}{0.10} \\
\hline Reduction $\%$ & \multicolumn{4}{|c|}{3} & \multicolumn{4}{|c|}{6} \\
\hline \multicolumn{9}{|c|}{ Effect of barley genotypes } \\
\hline \multirow{3}{*}{ Genotype } & \multirow{2}{*}{\multicolumn{2}{|c|}{ Means }} & \multicolumn{6}{|c|}{ Interaction } \\
\hline & & & \multicolumn{3}{|c|}{ NAR 1} & \multicolumn{3}{|c|}{ NAR 2} \\
\hline & NAR 1 & NAR 2 & Irrigated & Stressed & $\begin{array}{c}\text { Reduction } \\
\%\end{array}$ & Irrigated & Stressed & $\begin{array}{c}\text { Reduction } \\
\%\end{array}$ \\
\hline L 1 & 6.29 & 10.93 & 6.42 & 6.16 & 4 & 10.87 & 10.98 & -1 \\
\hline $\mathrm{L} 2$ & 6.32 & 11.52 & 6.59 & 6.05 & 8 & 11.59 & 11.44 & 1 \\
\hline L 3 & 6.46 & 11.49 & 6.83 & 6.09 & 11 & 11.90 & 11.08 & 7 \\
\hline L 4 & 6.52 & 11.87 & 6.50 & 6.54 & -1 & 12.48 & 11.26 & 10 \\
\hline L 5 & 6.40 & 11.47 & 6.51 & 6.29 & 3 & 12.10 & 10.85 & 10 \\
\hline L 6 & 6.37 & 11.69 & 6.41 & 6.33 & 1 & 12.07 & 11.30 & 6 \\
\hline L 7 & 6.52 & 11.54 & 6.43 & 6.60 & -3 & 11.74 & 11.34 & 3 \\
\hline L 8 & 6.68 & 11.70 & 6.83 & 6.52 & 5 & 12.23 & 11.17 & 9 \\
\hline L9 & 6.67 & 11.79 & 6.64 & 6.69 & -1 & 12.55 & 11.02 & 12 \\
\hline L 10 & 6.55 & 11.46 & 6.69 & 6.40 & 4 & 11.59 & 11.33 & 2 \\
\hline L 11 & 6.63 & 11.62 & 6.62 & 6.65 & 0 & 11.92 & 11.32 & 5 \\
\hline L 12 & 6.55 & 11.08 & 6.87 & 6.23 & 9 & 11.05 & 11.12 & -1 \\
\hline L 13 & 6.36 & 10.91 & 6.48 & 6.25 & 4 & 11.07 & 10.75 & 3 \\
\hline L 14 & 6.24 & 11.61 & 6.23 & 6.25 & 0 & 11.82 & 11.41 & 3 \\
\hline L 15 & 6.48 & 11.80 & 6.58 & 6.37 & 3 & 12.26 & 11.33 & 8 \\
\hline L 16 & 5.97 & 11.55 & 5.93 & 6.02 & -1 & 12.07 & 11.03 & 9 \\
\hline Beacher & 6.19 & 11.66 & 6.52 & 5.87 & 10 & 12.61 & 10.71 & 15 \\
\hline Giza 121 & 6.46 & 11.93 & 6.60 & 6.31 & 4 & 12.95 & 10.91 & 16 \\
\hline Giza 126 & 6.59 & 11.00 & 6.54 & 6.63 & -1 & 10.84 & 11.17 & -3 \\
\hline Giza 132 & 6.72 & 11.75 & 6.92 & 6.52 & 6 & 11.99 & 11.51 & 4 \\
\hline LSD 0.05 & 0.15 & 0.33 & \multicolumn{2}{|c|}{0.21} & -- & \multicolumn{2}{|c|}{0.46} & -- \\
\hline
\end{tabular}

\section{Relative growth rate ( $R G R)$}

Relative growth rate exhibited the highest value in the irrigated treatment and the lowest value obtained from the stressed treatment (Fig. 3). The reduction percentage was 1 and $9 \%$ at 45-65 and 65-85 days, respectively. The smaller TDM and CGR may be responsible for the significant decrease in RGR. These results are in agreement with those obtained by Alam (2003) and Moayedi et al. (2011). L10 and L12 had the highest values in the two growth intervals under the stressed treatment compared to Giza 126 (Table 9).

Egypt. J. Agron. 35, No. 1 (2013) 
TABLE 9. Relative growth rate (RGR) means as affected by irrigation treatments and barley genotypes as well as its interaction at two growth intervals in combined data of both growing seasons.

\begin{tabular}{|c|c|c|c|c|c|c|c|c|}
\hline \multicolumn{9}{|c|}{ 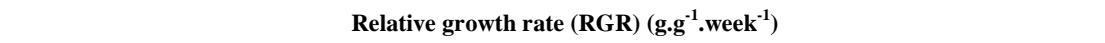 } \\
\hline \multicolumn{9}{|c|}{ Effect of irrigation treatments } \\
\hline Treatment & \multicolumn{4}{|c|}{ RGR 1 } & \multicolumn{4}{|c|}{ RGR 2} \\
\hline Irrigated & \multicolumn{4}{|c|}{0.102} & \multicolumn{4}{|c|}{0.106} \\
\hline Stressed & \multicolumn{4}{|c|}{0.101} & \multicolumn{4}{|c|}{0.096} \\
\hline LSD 0.05 & \multicolumn{4}{|c|}{0.0007} & \multicolumn{4}{|c|}{0.0007} \\
\hline Reduction\% & \multicolumn{4}{|c|}{1} & \multicolumn{4}{|c|}{9} \\
\hline \multicolumn{9}{|c|}{ Effect of barley genotypes } \\
\hline \multirow{3}{*}{ Genotype } & \multirow{2}{*}{\multicolumn{2}{|c|}{ Means }} & \multicolumn{6}{|c|}{ Interaction } \\
\hline & & & \multicolumn{3}{|c|}{ RGR 1} & \multicolumn{3}{|c|}{ RGR 2} \\
\hline & RGR 1 & RGR 2 & Irrigated & Stressed & Reduction \% & Irrigated & Stressed & Reduction \% \\
\hline L 1 & 0.107 & 0.100 & 0.106 & 0.108 & -2 & 0.102 & 0.098 & 3 \\
\hline $\mathrm{L} 2$ & 0.099 & 0.103 & 0.106 & 0.093 & 12 & 0.107 & 0.098 & 9 \\
\hline L 3 & 0.105 & 0.101 & 0.106 & 0.105 & 1 & 0.104 & 0.099 & 5 \\
\hline L 4 & 0.095 & 0.099 & 0.095 & 0.095 & 0 & 0.106 & 0.092 & 13 \\
\hline L 5 & 0.097 & 0.100 & 0.096 & 0.097 & -1 & 0.106 & 0.095 & 10 \\
\hline L 6 & 0.097 & 0.101 & 0.097 & 0.096 & 1 & 0.107 & 0.096 & 10 \\
\hline L 7 & 0.102 & 0.102 & 0.098 & 0.106 & -8 & 0.106 & 0.098 & 8 \\
\hline L 8 & 0.099 & 0.100 & 0.100 & 0.098 & 2 & 0.106 & 0.094 & 11 \\
\hline L 9 & 0.103 & 0.102 & 0.102 & 0.104 & -2 & 0.109 & 0.094 & 14 \\
\hline L 10 & 0.111 & 0.105 & 0.113 & 0.109 & 4 & 0.109 & 0.101 & 7 \\
\hline L 11 & 0.101 & 0.099 & 0.102 & 0.100 & 2 & 0.106 & 0.093 & 13 \\
\hline \begin{tabular}{|ll}
$\mathrm{L} 12$ \\
\end{tabular} & 0.114 & 0.104 & 0.120 & 0.109 & 9 & 0.106 & 0.102 & 4 \\
\hline L 13 & 0.106 & 0.100 & 0.108 & 0.104 & 4 & 0.105 & 0.095 & 9 \\
\hline L 14 & 0.099 & 0.103 & 0.097 & 0.101 & -5 & 0.107 & 0.098 & 8 \\
\hline L 15 & 0.100 & 0.102 & 0.101 & 0.100 & 1 & 0.108 & 0.096 & 11 \\
\hline L 16 & 0.098 & 0.105 & 0.095 & 0.102 & -8 & 0.110 & 0.100 & 9 \\
\hline Beacher & 0.103 & 0.104 & 0.108 & 0.098 & 9 & 0.113 & 0.095 & 16 \\
\hline \begin{tabular}{|l|} 
Giza 121 \\
\end{tabular} & 0.100 & 0.102 & 0.101 & 0.099 & 2 & 0.110 & 0.095 & 14 \\
\hline \begin{tabular}{|l|} 
Giza 126 \\
\end{tabular} & 0.100 & 0.095 & 0.099 & 0.101 & -2 & 0.097 & 0.094 & 3 \\
\hline Giza 132 & 0.100 & 0.100 & 0.101 & 0.099 & 2 & 0.104 & 0.097 & 7 \\
\hline LSD 0.05 & 0.002 & 0.002 & \multicolumn{2}{|c|}{0.003} & -- & \multicolumn{2}{|c|}{0.003} & -- \\
\hline
\end{tabular}

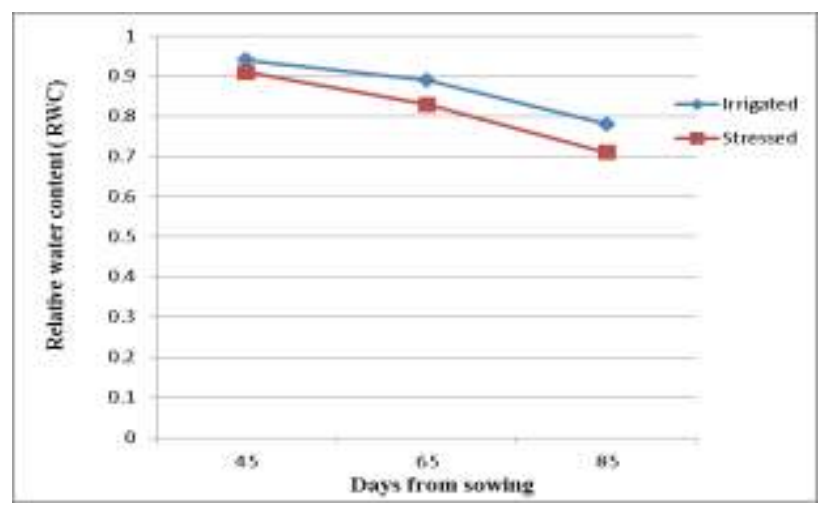

Fig. 3. Trend of relative water content under irrigated and stressed conditions. 


\section{Relative water content ( $R W C$ )}

The relative water content was demonstrated to be a relevant screening tool of drought tolerance in cereals, as well as a good indicator of plant water-status relative to their fully turgid condition. During the drought stress, relative growth rates were more reduced. Maintenance of relative water content contributes to the increased yield and yield stability under drought, in cereals.

Results showed highly significant differences on RWC due to irrigation treatments at both growth intervals (Table 10). In general, the RWC means in the stressed treatment were significantly lower than the irrigated treatment, where the RWC reduction as the result of water stress. RWC changes resembled in both treatments, but the irrigated treatment had superiority over that of the stressed treatment during all the stages. These results are in agreement with those obtained by Klar \& Santos (2008), Sorin et al. (2008) and Vaezi et al. (2010). Genotype Giza132 had a higher value under the stressed treatment compared to Giza 126.

TABLE 10. Relative water content (RWC) means as affected by irrigation treatments and barley genotypes as well as its interaction at three growth stages in combined data of both growing seasons.

\begin{tabular}{|c|c|c|c|c|c|c|c|c|c|c|c|c|}
\hline \multicolumn{13}{|c|}{ Relative water content ( RWC) } \\
\hline \multicolumn{13}{|c|}{ Effect of irrigation treatments } \\
\hline Treatment & \multicolumn{4}{|c|}{ Sample 1} & \multicolumn{5}{|c|}{ Sample 2} & \multicolumn{3}{|c|}{ Sample 3} \\
\hline Irrigated & \multicolumn{4}{|c|}{0.94} & \multicolumn{5}{|c|}{0.89} & \multicolumn{3}{|c|}{0.78} \\
\hline Stressed & \multicolumn{4}{|c|}{0.91} & \multicolumn{5}{|c|}{0.83} & \multicolumn{3}{|c|}{0.71} \\
\hline LSD 0.05 & \multicolumn{4}{|c|}{0.003} & \multicolumn{5}{|c|}{0.004} & \multicolumn{3}{|c|}{0.007} \\
\hline Reduction $\%$ & \multicolumn{4}{|c|}{3} & \multicolumn{4}{|c|}{7} & & \multicolumn{3}{|c|}{9} \\
\hline \multicolumn{13}{|c|}{ Effect of barley genotypes } \\
\hline \multirow{3}{*}{ Genotype } & \multirow{2}{*}{\multicolumn{3}{|c|}{ Means }} & \multicolumn{9}{|c|}{ Interaction } \\
\hline & & & & \multicolumn{3}{|c|}{ Sample 1} & \multicolumn{3}{|c|}{ Sample 2} & \multicolumn{3}{|c|}{ Sample 3} \\
\hline & $\begin{array}{c}\text { Sample } \\
1 \\
\end{array}$ & \begin{tabular}{|c|} 
Sample \\
2 \\
\end{tabular} & $\begin{array}{c}\text { Sample } \\
3 \\
\end{array}$ & Irrigated & Stressed & $\begin{array}{c}\text { Reduction } \\
\%\end{array}$ & Irrigated & Stressed & $\begin{array}{c}\text { Reduction } \\
\%\end{array}$ & Irrigated & Stressed & $\begin{array}{c}\text { Reduction } \\
\%\end{array}$ \\
\hline $\mathrm{L} 1$ & 0.92 & 0.88 & 0.73 & 0.96 & 0.91 & 5 & 0.90 & 0.86 & 5 & 0.78 & 0.67 & 14 \\
\hline $\mathrm{L} 2$ & 0.92 & 0.88 & 0.70 & 0.97 & 0.92 & 5 & 0.90 & 0.86 & 5 & 0.75 & 0.66 & 12 \\
\hline L 3 & 0.94 & \begin{tabular}{|l|}
0.84 \\
\end{tabular} & 0.75 & 0.94 & 0.90 & 4 & 0.90 & 0.78 & 13 & 0.77 & 0.73 & 6 \\
\hline $\mathrm{L} 4$ & 0.92 & 0.88 & 0.78 & 0.93 & 0.91 & 2 & 0.90 & 0.85 & 6 & 0.82 & 0.74 & 9 \\
\hline L 5 & 0.92 & 0.87 & 0.77 & 0.93 & 0.92 & 1 & 0.89 & 0.86 & 3 & 0.81 & 0.73 & 10 \\
\hline L 6 & 0.93 & 0.88 & 0.73 & 0.95 & 0.93 & 2 & 0.89 & 0.86 & 3 & 0.78 & 0.68 & 13 \\
\hline L 7 & 0.94 & 0.78 & 0.68 & 0.86 & \begin{tabular}{l|l}
0.80 \\
\end{tabular} & 7 & 0.82 & 0.73 & 11 & 0.71 & 0.65 & 8 \\
\hline L 8 & 0.83 & 0.82 & 0.79 & 0.93 & 0.92 & 1 & 0.86 & 0.79 & 8 & 0.80 & 0.77 & 4 \\
\hline L9 & 0.93 & \begin{tabular}{|l|}
0.86 \\
\end{tabular} & 0.74 & 0.94 & 0.90 & 4 & 0.88 & 0.83 & 5 & 0.81 & 0.67 & 17 \\
\hline L 10 & 0.92 & \begin{tabular}{|l|}
0.88 \\
\end{tabular} & 0.77 & 0.95 & \begin{tabular}{l|l|}
0.94 \\
\end{tabular} & 1 & 0.89 & 0.86 & 3 & 0.78 & 0.76 & 2 \\
\hline L 11 & 0.93 & 0.91 & 0.79 & 0.95 & 0.90 & 5 & 0.92 & 0.89 & 3 & 0.84 & 0.74 & 12 \\
\hline L 12 & 0.92 & 0.85 & 0.69 & 0.93 & 0.92 & 1 & 0.87 & 0.83 & 5 & 0.74 & 0.64 & 14 \\
\hline L 13 & 0.94 & 0.86 & 0.71 & 0.97 & 0.90 & 7 & 0.88 & 0.83 & 6 & 0.73 & 0.68 & 7 \\
\hline L 14 & 0.92 & \begin{tabular}{|l|}
0.87 \\
\end{tabular} & 0.73 & 0.96 & \begin{tabular}{l|l|}
0.88 \\
\end{tabular} & 8 & 0.88 & 0.85 & 4 & 0.78 & 0.67 & 14 \\
\hline L 15 & 0.92 & 0.86 & 0.70 & 0.93 & 0.91 & 2 & 0.88 & 0.83 & 6 & 0.73 & 0.68 & 7 \\
\hline L 16 & 0.94 & 0.87 & 0.74 & 0.95 & \begin{tabular}{l|l|}
0.93 \\
\end{tabular} & 2 & 0.91 & 0.83 & 9 & 0.77 & 0.71 & 8 \\
\hline Beacher & 0.93 & 0.85 & 0.73 & 0.93 & 0.90 & 3 & 0.90 & 0.80 & 11 & 0.78 & 0.68 & 13 \\
\hline Giza 121 & 0.92 & \begin{tabular}{|l|}
0.84 \\
\end{tabular} & 0.81 & 0.93 & \begin{tabular}{l|l|}
0.92 \\
\end{tabular} & 1 & 0.86 & 0.82 & 4 & 0.82 & 0.80 & 3 \\
\hline Giza 126 & 0.95 & 0.85 & 0.77 & 0.95 & 0.92 & 3 & 0.89 & 0.81 & 9 & 0.82 & 0.72 & 12 \\
\hline Giza 132 & 0.95 & \begin{tabular}{|l|}
0.88 \\
\end{tabular} & 0.83 & 0.95 & 0.89 & 6 & 0.89 & 0.87 & 2 & 0.84 & 0.81 & 3 \\
\hline LSD 0.05 & 0.01 & 0.01 & 0.02 & \multicolumn{2}{|c|}{0.02} & -- & \multicolumn{2}{|c|}{0.02} & -- & \multicolumn{2}{|c|}{0.03} & -- \\
\hline
\end{tabular}




\section{Relative chlorophyll content}

The stressed treatment resulted in higher RCC, compared with the irrigated treatment in three growth stages (Fig. 4). Photosynthesis per unit leaf area was not initially reduced by stress, particularly in the more-tolerant genotypes, as the chlorophyll per unit area was higher under stress than under non-stress conditions (the leaves were narrower, the cells were smaller, and so the chloroplast density was greater) (Munns et al., 2006). For mean values, Giza 132, Giza 121, L2, L4, L8, L10 and L12 genotypes gave the highest values for relative chlorophyll content compared to Giza 126 (Table 11). While, Giza 121, L4, L8 and L12 had higher values under the stressed treatment in the three samples. These results agreed with Ali et al. (2009).

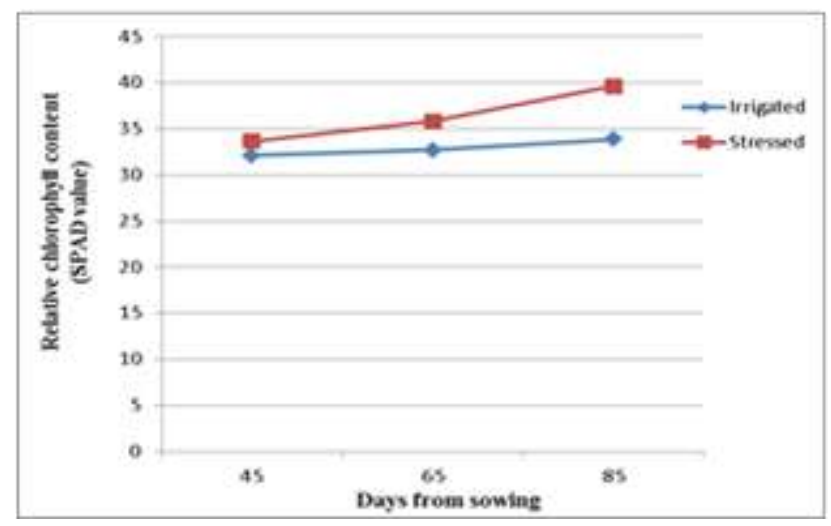

Fig. 4. Trend of relative chlorophyll content under irrigated and stressed conditions.

\section{Grain yield}

As drought stress severity increased, grain yield decreased for all genotypes in both seasons (Table 12). The percentage of reduction in grain yield by the severe drought stress treatment was $37 \%, 36 \%$ and $36 \%$ in the first, the second season and combined analysis, respectively. Average yields in irrigated treatment varied from 3150 to $4143 \mathrm{~kg}$. fed $^{-1}$, and in the stressed treatment, they varied from 1999 to $2639 \mathrm{~kg}$. fed $\mathrm{f}^{-1}$ in the first and the second seasons, respectively. Under both water stress and irrigated conditions, L4 revealed the highest grain yield for two years. These results agreed with Bagheri et al. (2007) Santos et al. (2008) Samarah el al. (2009), Refay (2010) and Vaezi el al. (2010).

The grain yield under stress environments is dependent upon stress susceptibility yield potential. The susceptibility of a plant genotype to stress in the product of many physiological and morphological traits for which effective selection criteria have not yet been developed (Fisher \& Maure, 1978). Therefore, grain yield and attributes remain as major selection criteria for improved adaptation to stress environments in many breeding programs. 
TABLE 11. Relative chlorophyll content (SPAD value) means as affected by irrigation treatments and barley genotypes as well as its interaction at three growth stages in combined data of both growing seasons.

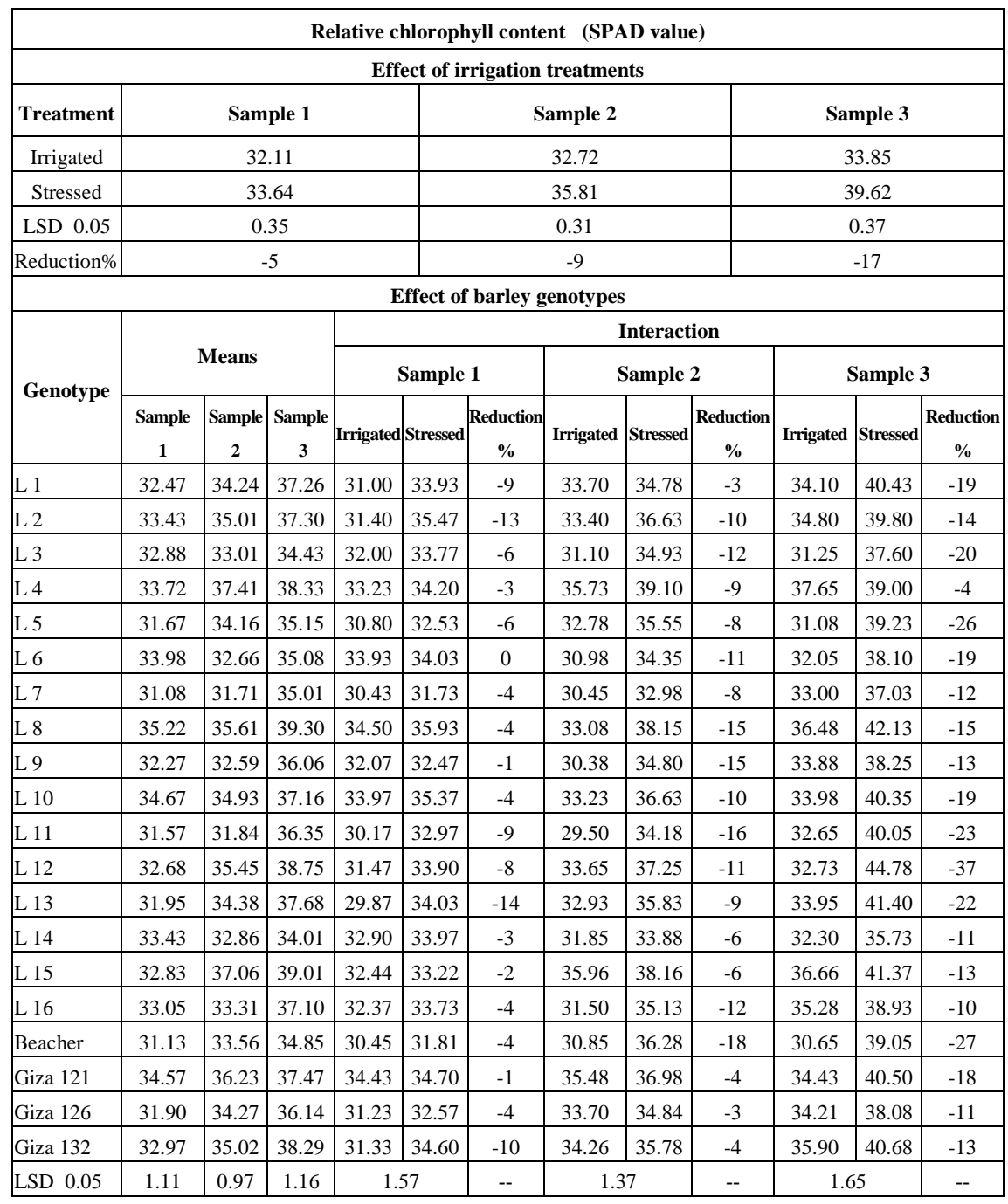

As a result of water stress condition, the average of grain yield for these genotypes decreased. Several authors reported that, drought stress reduced photosynthesis and translocation rates and increased respiration, which reduced available assimilates for grain filling and finally decreased grain yield (ElNaggar, 2010 and Zare el al., 2011).

Egypt. J. Agron. 35, No. 1 (2013) 
TABLE 12. Mean values of the effect of irrigation treatments, comparison among barley genotype means and effect of the interaction between barley genotypes and irrigation treatments on grain yield $\left(\mathrm{kg}^{\text {. fed }}{ }^{-1}\right)$ in both growing seasons and combined.

\begin{tabular}{|c|c|c|c|c|c|c|c|c|c|c|c|c|}
\hline \multicolumn{13}{|c|}{ Effect of irrigation treatments } \\
\hline Treatment & \multicolumn{4}{|c|}{$2009 / 10$} & \multicolumn{5}{|c|}{$2010 / 11$} & \multicolumn{3}{|c|}{ Comb. } \\
\hline Irrigated & \multicolumn{4}{|c|}{3150} & \multicolumn{5}{|c|}{4143} & \multicolumn{3}{|c|}{3647} \\
\hline Stressed & \multicolumn{4}{|c|}{1999} & \multicolumn{5}{|c|}{2639} & \multicolumn{3}{|c|}{2319} \\
\hline LSD 0.05 & \multicolumn{4}{|c|}{77} & \multicolumn{5}{|c|}{152} & \multicolumn{3}{|c|}{85} \\
\hline Reduction $\%$ & \multicolumn{4}{|c|}{37} & \multicolumn{5}{|c|}{36} & \multicolumn{3}{|c|}{36} \\
\hline \multicolumn{13}{|c|}{ Effect of barley genotypes } \\
\hline \multirow{3}{*}{ Genotype } & \multirow{2}{*}{\multicolumn{3}{|c|}{ Means }} & \multicolumn{9}{|c|}{ Interaction } \\
\hline & & & & \multicolumn{3}{|c|}{$2009 / 10$} & \multicolumn{3}{|c|}{ 2010/11 } & \multicolumn{3}{|c|}{ Comb. } \\
\hline & $2009 / 10$ & $2010 / 11$ & Comb. & Irrigated & Stressed & $\begin{array}{c}\text { Reduction } \\
\%\end{array}$ & Irrigated & Stressed & $\begin{array}{c}\text { Reduction } \\
\%\end{array}$ & Irrigated & Stressed & \begin{tabular}{|c} 
Reduction \\
$\%$
\end{tabular} \\
\hline L 1 & 2361 & 3194 & 2777 & 3108 & 1615 & 48 & 4225 & 2163 & 49 & 3666 & 1889 & 48 \\
\hline $\mathrm{L} 2$ & 2617 & 3613 & 3115 & 3184 & 2050 & 36 & 4375 & 2850 & 35 & 3780 & 2450 & 35 \\
\hline L 3 & 2285 & 3094 & 2689 & 2883 & 1687 & 41 & 3963 & 2225 & 44 & 3423 & 1956 & 43 \\
\hline $\mathrm{L} 4$ & 3018 & 4250 & 3634 & 3536 & 2500 & 29 & 4925 & 3575 & 27 & 4231 & 3037 & 28 \\
\hline L 5 & 2687 & 3625 & 3156 & 3262 & 2112 & 35 & 4400 & 2850 & 35 & 3831 & 2481 & 35 \\
\hline L 6 & 2768 & 3744 & 3256 & 3409 & 2128 & 38 & 4613 & 2875 & 38 & 4011 & 2501 & 38 \\
\hline L 7 & 2341 & 3106 & 2723 & 2863 & 1819 & 36 & 3863 & 2350 & 39 & 3363 & 2084 & 38 \\
\hline L 8 & 2812 & 3725 & 3268 & 3372 & 2252 & 33 & 4300 & 3150 & 27 & 3836 & 2701 & 30 \\
\hline L9 & 2570 & 3381 & 2976 & 3000 & 2140 & 29 & 3888 & 2875 & 26 & 3444 & 2507 & 27 \\
\hline $\mathrm{L} 10$ & 2275 & 2963 & 2619 & 2726 & 1823 & 33 & 3475 & 2450 & 29 & 3101 & 2136 & 31 \\
\hline L 11 & 2794 & 3725 & 3259 & 3511 & 2077 & 41 & 4638 & 2813 & 39 & 4074 & 2445 & 40 \\
\hline L 12 & 2473 & 3125 & 2799 & 3152 & 1795 & 43 & 4025 & 2225 & 45 & 3588 & 2010 & 44 \\
\hline L 13 & 2502 & 3163 & 2832 & 3085 & 1918 & 38 & 3838 & 2488 & 35 & 3461 & 2203 & 36 \\
\hline L 14 & 2479 & 3206 & 2842 & 3188 & 1770 & 44 & 4125 & 2288 & 45 & 3656 & 2029 & 45 \\
\hline L 15 & 2514 & 3356 & 2935 & 3052 & 1975 & 35 & 4063 & 2650 & 35 & 3557 & 2313 & 35 \\
\hline L 16 & 2556 & 2963 & 2759 & 3071 & 2041 & 34 & 3788 & 2138 & 44 & 3429 & 2089 & 39 \\
\hline Beacher & 2447 & 3069 & 2758 & 2911 & 1984 & 32 & 3638 & 2500 & 31 & 3274 & 2242 & 32 \\
\hline Giza 121 & 2640 & 3488 & 3064 & 3204 & 2075 & 35 & 4200 & 2775 & 34 & 3702 & 2425 & 34 \\
\hline Giza 126 & 2682 & 3519 & 3100 & 3240 & 2123 & 34 & 4238 & 2800 & 34 & 3739 & 2462 & 34 \\
\hline Giza 132 & 2671 & 3513 & 3092 & 3246 & 2097 & 35 & 4288 & 2738 & 36 & 3767 & 2417 & 36 \\
\hline LSD 0.05 & 243 & 482 & 269 & - & - & -- & -- & & -- & -- & & -- \\
\hline
\end{tabular}

\section{Biological yield}

Results show highly significant differences among irrigation treatments in both seasons, where the irrigated treatment outyielded the stressed treatment (Table 13). The reduction percentage was 41,46 and $44 \%$ at the first season, the second and combined, respectively. These results are confirmed by Bayoumi (2004), Bagheri et al. (2007) and Refay (2010). Biological yield differences were related to low plant height, leaf area and tiller numbers; grain yield differences were caused by a reduction in spikes/plant and grains/spike. Genotypes Giza132, 
L4 and L8 produced the highest values compared with Giza 126, while Beacher, L1, L10 and L12 recorded the lowest genotypes in both seasons.

TABLE 13. Mean values of the effect of irrigation treatments, comparison among barley genotype means and effect of the interaction between barley genotypes and irrigation treatments on biological yield $\left(\mathrm{kg}^{.} \mathrm{fed}^{-1}\right)$ in both growing seasons and combined.

\begin{tabular}{|c|c|c|c|c|c|c|c|c|c|c|c|c|}
\hline \multicolumn{13}{|c|}{ Effect of irrigation treatments } \\
\hline Treatment & \multicolumn{4}{|c|}{$2009 / 10$} & \multicolumn{5}{|c|}{$2010 / 11$} & \multicolumn{3}{|c|}{ Comb. } \\
\hline Irrigated & \multicolumn{4}{|c|}{9100} & \multicolumn{5}{|c|}{11550} & \multicolumn{3}{|c|}{10325} \\
\hline Stressed & \multicolumn{4}{|c|}{5394} & \multicolumn{5}{|c|}{6199} & \multicolumn{3}{|c|}{5796} \\
\hline LSD 0.05 & \multicolumn{4}{|c|}{174} & \multicolumn{5}{|c|}{379} & \multicolumn{3}{|c|}{211} \\
\hline Reduction \% & \multicolumn{3}{|c|}{41} & & \multicolumn{5}{|c|}{46} & \multicolumn{3}{|c|}{44} \\
\hline \multicolumn{13}{|c|}{ Effect of barley genotypes } \\
\hline \multirow{3}{*}{ Genotype } & \multirow{2}{*}{\multicolumn{3}{|c|}{ Means }} & \multicolumn{9}{|c|}{ Interaction } \\
\hline & & & & \multicolumn{3}{|c|}{$2009 / 10$} & \multicolumn{3}{|c|}{$2010 / 11$} & \multicolumn{3}{|c|}{ Comb. } \\
\hline & $2009 / 10$ & $2010 / 11$ & Comb. & Irrigated & Stressed & $\begin{array}{c}\text { Reduction } \\
\%\end{array}$ & Irrigated & Stressed & d $\begin{array}{c}\text { Reduction } \\
\%\end{array}$ & Irrigated & Stressed & $\begin{array}{c}\text { Reduction } \\
\%\end{array}$ \\
\hline L 1 & 6426 & 7950 & 7188 & 8825 & 4028 & 54 & 11250 & 4650 & 59 & 10038 & 4339 & 57 \\
\hline L 2 & 7015 & 8275 & 7645 & 8665 & 5366 & 38 & 10450 & 6100 & 42 & 9558 & 5733 & 40 \\
\hline L 3 & 7236 & 9275 & 8256 & 9283 & 5189 & 44 & 12500 & 6050 & 52 & 10892 & 5620 & 48 \\
\hline L 4 & 8159 & 10163 & 9161 & 9820 & 6498 & 34 & 12625 & 7700 & 39 & 11222 & 7099 & 37 \\
\hline L 5 & 7459 & 9638 & 8548 & 9064 & 5853 & 35 & 12400 & 6875 & 45 & 10732 & 6364 & 41 \\
\hline L 6 & 7512 & 9350 & 8431 & 9367 & 5658 & 40 & 12000 & 6700 & 44 & 10683 & 6179 & 42 \\
\hline L 7 & 7190 & 8900 & 8045 & 9311 & 5068 & 46 & 11950 & 5850 & 51 & 10630 & 5459 & 49 \\
\hline L 8 & 7928 & 9988 & 8958 & 9929 & 5927 & 40 & 12625 & 7350 & 42 & 11277 & 6639 & 41 \\
\hline L 9 & 7053 & 9038 & 8045 & 8546 & 5560 & 35 & 11200 & 6875 & 39 & 9873 & 6217 & 37 \\
\hline L 10 & 6419 & 7700 & 7060 & 8005 & 4833 & 40 & 9725 & 5675 & 42 & 8865 & 5254 & 41 \\
\hline L 11 & 7234 & 9275 & 8255 & 9292 & 5177 & 44 & 11950 & 6600 & 45 & 10621 & 5888 & 45 \\
\hline L 12 & 6440 & 7425 & 6932 & 8104 & 4776 & 41 & 9750 & 5100 & 48 & 8927 & 4938 & 45 \\
\hline L 13 & 7130 & 8438 & 7784 & 9188 & 5073 & 45 & 11250 & 5625 & 50 & 10219 & 5349 & 48 \\
\hline $\mathrm{L} 14$ & 7152 & 8738 & 7945 & 9054 & 5251 & 42 & 11375 & 6100 & 46 & 10215 & 5675 & 44 \\
\hline L 15 & 7140 & 8738 & 7939 & 8868 & 5413 & 39 & 11350 & 6125 & 46 & 10109 & 5769 & 43 \\
\hline L 16 & 7627 & 8175 & 7901 & 9346 & 5907 & 37 & 10750 & 5600 & 48 & 10048 & 5754 & 43 \\
\hline Beacher & 6755 & 7975 & 7365 & 8468 & 5042 & 40 & 10200 & 5750 & 44 & 9334 & 5396 & 42 \\
\hline Giza 121 & 7354 & 8925 & 8139 & 9107 & 5600 & 39 & 11600 & 6250 & 46 & 10354 & 5925 & 43 \\
\hline Giza 126 & 7607 & 9225 & 8416 & 9339 & 5875 & 37 & 12000 & 6450 & 46 & 10669 & 6163 & 42 \\
\hline Giza 132 & 8102 & 10300 & 9201 & 10420 & 5783 & 45 & 14050 & 6550 & 53 & 12235 & 6166 & 50 \\
\hline LSD 0.05 & 550 & 1198 & 666 & - & - & -- & -- & & -- & 94 & 42 & -- \\
\hline
\end{tabular}

The interaction between the irrigated treatments and barley genotypes was non-significant in both growing seasons. These results are confirmed by Khayatnezhad el al. (2010), Refay (2010), Mollah \& Paul (2011) and Zare el al. (2011).

Egypt. J. Agron. 35, No. 1 (2013) 


\section{Conclusion}

Generally, all the studied characteristics were significantly affected by water stress at both growing seasons, except for total chlorophyll content. Grain yield was the highest in Giza132, L2, L4, L5, L6, L8 and L11compared with Giza126 (as a check). L4 and L8 genotypes had the highest values of TDM, LAI and CGR especially under stress condition, as well as possessed high values of NAR, RGR and RCC.

\section{References}

Alam, M.Z., Rahman, M.S., Hossain, M.E., Azad, M.A.K. and Khan, M.R.H. (2003) Response of irrigation frequencies and different doses of $\mathrm{N}$ fertilization on the growth and yield of wheat. Pakistan Journal of Biological Sciences, 6 (8), 732-734.

Ali, A.A., Ahmed, I.A. and Abd EL-Aziem, A.M. (2009) Genetic evaluation and marker-assisted selection for drought tolerance in barley. African Crop Sci. Conference Proceedings, 9, 399-406

Amer, Kh. A. (2010) Inheritance of drought tolerance in some barley genotypes. Egypt. J. Agric., Res., 88(1), 85-102.

Bagheri, A. and Abad, H.HS. (2007) Effect of drought and salt stresses on yield, yield components, and ion content of hull-less barley (Hordeum sativum L.). J. new Agric. Sci. 3 (7), 1-15.

Barrs, H.D. (1968) Determination of water deficit in plant tissues. In: " Water Deficits and Plant Growth" Kozlouski T.T. (Ed.), pp. 235-268. Academic Press New-Delhi, 1.

Bayoumi, T.Y. (2004) Diallel cross analysis for bread wheat under stress and normal irrigation treatments. Zagazig J. Agric. Res. 31 (2), 435-455.

El-Naggar, A.A.E.A. (2010) Genetical studies on drought tolerance of barley. M.Sc. Thesis, Fac. of Agric., Tanta Univ., Egypt.

Fisher, R.A. and Maurer, R. (1978) Drought resistance in spring wheat cultivars I. Grain yield responses. Aust. J. Agric. Res. 29, 897-912.

Jazy, H.D., Poor, M.R.K., Abad, H.H.S. and Soleimani, A. (2007) Growth indices of winter wheat as affected by irrigation regimes under Iran conditions. Pakistan Journal of Biological Sciences, 10 (24), 4495-4499.

Katta, Y.S., Eid, A.A., Abd El-Aty, M.S. and EL-Wakeel, Sally M. (2009) Studies on tolerance of some hulless barley crosses to drought. $6^{\text {th }}$ International Plant Breeding Conference, Ismalia, Egypt. May 3-5: pp.867-885.

Khayatnezhad, M., Zaefizadeh, M., Gholamin, R., Somarin, S.J. and Mahmoodabad, R.Z. (2010) Study of morphological traits of wheat cultivars through factor analysis. Am-Euras. J. Agric. Environ. Sci. 9 (5), 460-464. 
Klar, A. and Santos, A. (2008) Influence of water stress on barley cultivars. Agricultural Engineering Department, FCA-Unesp, SP, Brazil. 23-25 June, 2008. pp. 179-183.

Moayedi, A.A., Boyce, A.N., Barakbah, S.S. and Kafi, M. (2011) Water deficit-induced changes on growth parameters and radiation use efficiency of promising durum wheat genotypes. J. Food, Agriculture \& Environment, 9 (1), 563-565.

Mollah, M.S.I. and Paul, N.K. (2008) Growth attributes of barley (Hordeum vulgare L.) in relation to soil moisture regimes and NPK fertilizers. J. Bio Sci. 16, 19-24.

Munns, R., James, R.A. and Läuchli, A. (2006) Approaches to increasing the salt tolerance of wheat and other cereals. Journal of Experimental Botany, 1025-1043.

Noaman, M.M. (2008) Barley development in Egypt. Proceedings of the $10^{\text {th }}$ International Barley Genetics Symposium., Alexandria, Egypt, pp.3-15.

Radford, P.J. (1967) Growth analysis formulae, their use and abuse. Crop Sci. 7 (3), 171175.

Refay, Y.A. (2010) Relative influence of water irrigation improving productivity of some barley genotypes under low rainfall conditions of Saudi Arabia. American-Eurasian J. Agric. and Environ. Sci. 7 (3), 320-326.

Samarah, N.H., Alqudah, A.M., Amayreh, J.A. and McAndrews, G.M. (2009) The Effect of late-terminal drought stress on yield components of four barley cultivars. $J$. Agronomy and Crop Science, 195 (6), 427- 441.

Santos, A.B.A., Klar, A.E. and Jadoski, C.J. (2008) Physiological parameters in barley cultivars under water stress. Departamento de Engenharia Rural, Faculdade de Ciencias Agrono, Universidade Estadual Paulista, Botucatu, SP, Brazil. IRRIGA. 2008. 13(4) pp. 438-448.

Sorin, C.I., Emilian, M.A., Adriana, C.I., Giancarla, V.E. and Sabin, C.H. (2008) Evaluation of drought tolerance in winter barley using different screening techniques. Horticulture Faculty, Banates University of Agricultural Sciences Timişoara, Calea Aradului 119, 300645 Timisoara, Romania

Vaezi, B., Bavei, V. and Shiran, B. (2010) Screening of barley genotypes for drought tolerance by agro-physiological traits in field condition. African Journal of Agricultural Research, 5 (9), 881-892.

Watson, D.J. (1952) The physiological basis of variation in yield. Annals of Botany, 4, 101-145.

Zare, M., Azizi, M.H. and Bazrafshan, F. (2011) Effect of drought stress on some agronomic traits in ten barley (Hordeum vulgar L.) cultivars. Tech. J. Engin. \& App. Sci. 1 (3), 57-62. 
GROWTH ANALYSIS AND YIELD RESPONSE...

تحليل النمو وإستجابة محصول الثعير تحت تأثير نظم الرى

السيد حامد السيد الصعيدى ، خيرى عبدالعزيز عامر" ، أمجد عبدالغفار الجمال

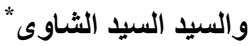

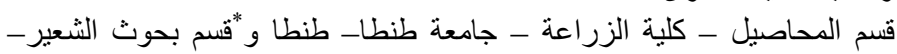
معهد بحوث المحاصيل الحقلية ـ مركز البحوث الزر اعية الزية ـ الجيزة ـ مصر.

لتقدير تحمل أربعه أصناف وستة عشر سلالة من الثعير للإجهاد المائى، تم قياس

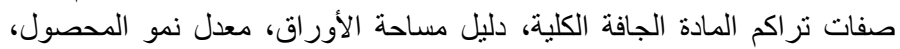

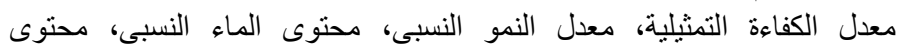

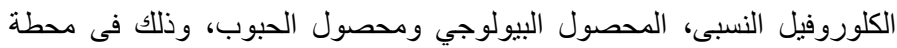

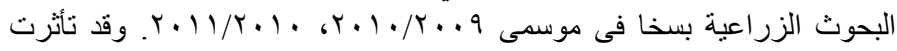

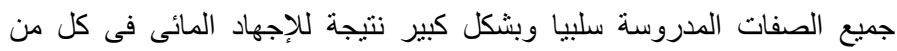

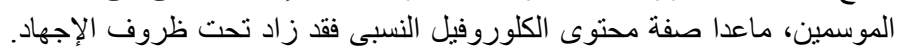

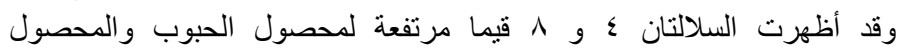

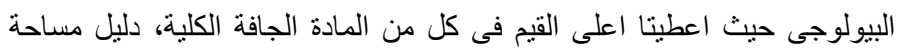

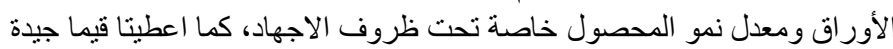

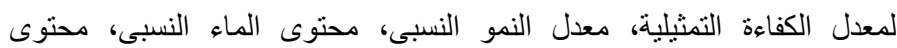

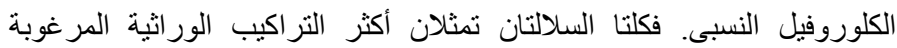
و المتحملة للإجهاد، وكذلك تحت ظروف لكن عدم الاجهاد. 